\title{
MMR
}

\section{Association between -44G/A and +71A/G polymorphisms in the connexin 40 gene and atrial fibrillation in Uyghur and Han populations in Xinjiang, China}

\author{
J. Hailati*, Y.C. Yang*, L. Zhang*, P.Y. He, M. Baikeyi, \\ W. Muhuyati and Z.Q. Liu \\ Heart Center, First Affiliated Hospital, Xinjiang Medical University, \\ Urumqi, China \\ *These authors contributed equally to this study. \\ Corresponding authors: W. Muhuyati / Z.Q. Liu \\ E-mail: muhuyati_dr@163.com / zqiangliu@126.com
}

Genet. Mol. Res. 15 (4): gmr15048628

Received March 21, 2016

Accepted June 27, 2016

Published October 17, 2016

DOI http://dx.doi.org/10.4238/gmr15048628

Copyright (C) 2016 The Authors. This is an open-access article distributed under the terms of the Creative Commons Attribution ShareAlike (CC BY-SA) 4.0 License.

\begin{abstract}
We aimed to elucidate the association between connexin $40(\mathrm{Cx} 40)$ genetic polymorphisms and atrial fibrillation (AF) in a Chinese population in Xinjiang comprising Uyghur and Han individuals. We enrolled 275 Uyghur and 305 age- and gendermatched Han subjects, and used polymerase chain reaction to detect single nucleotide polymorphisms (SNPs; $-44 \mathrm{G} / \mathrm{A}$ and $+71 \mathrm{~A} / \mathrm{G}$ ) in the gene encoding $\mathrm{Cx} 40$. A mutation screening was performed by direct sequencing and calculation of genotype and allele frequencies among AF patients and control subjects to determine the relationship between these variants and this condition in Uyghur and Han populations. The two SNPs examined were significantly associated with AF in both
\end{abstract}


ethnic groups. Further analysis showed the SNPs to be in perfect linkage disequilibrium in both $\mathrm{AF}$ and control groups among Uyghur and Han individuals. In both populations -44AA genotype and A allele frequencies among $\mathrm{AF}$ patients were significantly higher than those in the control group. In addition, under the dominant model (GG vs $\mathrm{GA}+\mathrm{AA}$ ), a significant difference in the distribution of $\mathrm{Cx} 40-44 \mathrm{G} /$ A genotypes was detected between patients and controls. Logistic regression analysis revealed that $\mathrm{Cx} 40$ genetic polymorphisms increase AF risk in Uyghur and Han residents of Xinjiang. In conclusion, both the $-44 \mathrm{G} / \mathrm{A}$ and $+71 \mathrm{~A} / \mathrm{G}$ variants of the gene encoding this protein are associated with AF in Uyghur and Han populations in northern China.

Key words: Atrial fibrillation; Connexin 40; Gene polymorphism

\section{INTRODUCTION}

Atrial fibrillation (AF) is the most common form of sustained clinical cardiac arrhythmia. It is characterized by fast atrial rhythm and uncoordinated atrial mechanical activity (January et al., 2014). Although AF is usually associated with cardiac pathology, including hypertensive heart disease, cardiomyopathy, valvular disease, or atherosclerotic cardiovascular disease, recent and increasing evidence points to an important heritable component, with significant genetic determinants. Scholars in China and elsewhere have described the mechanism underlying AF at the genetic level, and have established ethnic differences in the characteristics of genes encoding sodium channels, nitric oxide synthase, angiotensinogen, and gap junction protein 40 , thereby revealing polymorphisms related to this condition. It has been suggested that a common single nucleotide polymorphism (SNP) in the promoter of the gap junction protein connexin 40 (Cx40) GJA5 affects its activity and influences AF risk (Wirka et al., 2011).

$\mathrm{Cx} 40$, together with $\mathrm{Cx} 43$, is responsible for the electrical coupling of atrial cardiomyocytes. Several SNPs of the gene encoding Cx40 lead to abnormal connexin localization and impaired gap junction channels (Sun et al., 2014). This aberration may result in the development of AF. Two SNPs have been identified in GJA5 in the immediate upstream promoter region (-44G/A) and the untranslated region (+71A/G; Groenewegen et al., 2003). Some studies have suggested that these SNPs are robustly associated with AF in populations of European ancestry.

Epidemiological investigations have shown that the incidence of $\mathrm{AF}$ is $0.77 \%$ in China (Hu and Sun, 2008); however, among Uyghur adults of the Xinjiang region of this country, this figure is only $0.25 \%$ (Yao et al., 2010). AF incidence in the Uyghur population is distinctly lower than that in other ethnic groups, and their clinical characteristics differ from those of Han Chinese individuals (Mu et al., 2007a,b, 2008). This may be due not only to differences in lifestyle and eating habits, but also in heritable factors affecting AF. However, to date, no reports exist concerning the relationship between the Cx40 gene and AF among Uyghur and Han populations. This study aimed to explore any connection with GJA5 SNPs among Uyghur and Han patients, and identify potential ethnic differences. Furthermore, this study may provide the theoretical basis for future approaches to the diagnosis and treatment of $\mathrm{AF}$ among different ethnic groups in the Xinjiang region.

Genetics and Molecular Research 15 (4): gmr15048628 


\section{MATERIAL AND METHODS}

\section{Subjects}

Informed consent was obtained from all subjects according to the guidelines of the Medical Ethics Committee of the First Affiliated Hospital of Xinjiang Medical University. From January 2012 to January 2014, we recruited 580 patients from this hospital. The AF group consisted of 135 Uyghur (72 men and 63 women, aged 26 to 78 years) and 158 Han (87 men and 71 women, aged 27 to 80 years) patients. The control group included 140 Uyghur (67 men and 73 women, aged 26 to 83 years) and 147 Han (82 men and 65 women, aged 23 to 79 years) individuals with no history or electrocardiographic signs of AF. These subjects were matched to AF patients by ethnicity, age, and gender. AF evaluation was carried out by expert cardiologists according to the standard diagnostic criteria of the ACC/AHA/ESC 2006 guidelines for the management of AF patients (Fuster et al., 2006). Diagnoses were based on the replacement of sinus $\mathrm{P}$ waves by rapid oscillations or fibrillatory waves varying in size, shape, and timing, associated with an irregular ventricular response when atrioventricular conduction was intact. Clinical examinations were carried out using rest electrocardiography (ECG) or ambulatory Holter ECG recordings. Exclusion criteria were applied as in our previous study. All volunteers underwent physical examination, routine laboratory tests, ECG, chest X-ray, and echocardiography. In order to exclude subjects with structural heart disease, transthoracic and/or transesophageal echocardiography was performed. Systemic arterial hypertension was defined as a systolic blood pressure $\geq 140 \mathrm{mmHg}$ and/or a diastolic pressure $\geq 90 \mathrm{mmHg}$ (European Society of Hypertension-European Society of Cardiology Guidelines Committee, 2003). Participants smoking one cigarette or more per day for more than 1 year were categorized as smokers. Those smoking occasionally or rarely were deemed non-smokers. Drinking was defined as consuming an average $100 \mathrm{~mL}$ liquor daily (alcohol concentration above 50\%) for more than 1 year; subjects drinking occasionally or rarely were considered to be non-drinkers.

\section{Experimental methods}

\section{Biochemical analysis}

Venous blood samples $(5 \mathrm{~mL})$ were obtained after fasting overnight for at least 10 $\mathrm{h}$, before being centrifuged at $2500 \mathrm{~g}$ at $4^{\circ} \mathrm{C}$ for $30 \mathrm{~min}$. Sera were then immediately stored at $-80^{\circ} \mathrm{C}$ until analysis. Measurement of total cholesterol (TC), high-density lipoprotein cholesterol (HDL-C) and low-density lipoprotein cholesterol (LDL-C), triglycerides (TG), glucose, and uric acid was performed using standard methods in the Clinical Laboratory Department of the First Affiliated Hospital of Xinjiang Medical University.

\section{Genomic DNA isolation}

Peripheral whole blood samples were collected from participants after overnight fasting and stored in vacuum tubes containing $0.4 \%$ ethylenediaminetetraacetic acid as an anticoagulant. Genomic DNA was isolated and purified from these samples using a genomic DNA extraction kit (TIANGEN Biotech Corporation, Beijing, China). Extracted DNA was stored at $-20^{\circ} \mathrm{C}$ until use.

Genetics and Molecular Research 15 (4): gmr15048628 


\section{SNP genotyping}

The primers used are shown in Table 1. Each $50-\mu \mathrm{L}$ polymerase chain reaction (PCR) included the following reagents: $25 \mu \mathrm{L} 2 \mathrm{X}$ Es Taq master mix, $1.25 \mu \mathrm{L}$ forward primer (10 $\mathrm{pg} / \mu \mathrm{L}), 1.25 \mu \mathrm{L}$ reverse primer $(10 \mathrm{pg} / \mu \mathrm{L}), 4 \mu \mathrm{L}$ template DNA $(50 \mathrm{ng} / \mu \mathrm{L})$, and RNase-free water up to $50 \mu \mathrm{L}$. Reactions were thoroughly mixed by slight agitation and amplification was carried out on an Applied Biosystems (Foster City, CA, USA) 2720 thermal cycler.

Table 1. Primers used in connexin $40(\mathrm{Cx} 40)-44 \mathrm{G} / \mathrm{A}$ and $+71 \mathrm{~A} / \mathrm{G}$ polymerase chain reactions (PCRs).

\begin{tabular}{l|l|c|c}
\hline Polymorphism & Primer sequences & Annealing temperature $\left({ }^{\circ} \mathrm{C}\right)$ & PCR product (bp) \\
\hline Cx40 -44G/A & P1: 5'-TGAGGACAAGGACAACAGGCA G-3' & 60 & 400 \\
\hline & P2: 5'-CTTCCTCTGGCTACTTCATATC-3' & & \\
\hline $\mathrm{Cx} 40+71 \mathrm{~A} / \mathrm{G}$ & P1: 5'-GCTAAAGTCCAGGAAGAG-3' & 49.6 & 200 \\
\hline & P2: 5'-TTGGGAATGAGATAGTTT-3' & & \\
\hline
\end{tabular}

PCR conditions for the $\mathrm{Cx} 40-44 \mathrm{G} / \mathrm{A}$ SNP were as follows: initial denaturation at $95^{\circ} \mathrm{C}$ for $3 \mathrm{~min}, 34$ cycles of denaturation at $95^{\circ} \mathrm{C}$ for $30 \mathrm{~s}$, annealing at $60^{\circ} \mathrm{C}$ for $30 \mathrm{~s}$, and extension at $72^{\circ} \mathrm{C}$ for $1 \mathrm{~min}$, then a final extension at $72^{\circ} \mathrm{C}$ for $5 \mathrm{~min}$. The same conditions were used for the $+71 \mathrm{~A} / \mathrm{G}$ SNP, but with an annealing temperature of $49.6^{\circ} \mathrm{C}$ and 30 amplification cycles.

PCR products were stored at $4^{\circ} \mathrm{C}$. To determine the success of PCR amplification, products $(10 \mu \mathrm{L})$ were electrophoresed on a $1 \%$ gel. In addition, each PCR sample $(40 \mu \mathrm{L})$ was sent to Sangon Biotech Co., Ltd. (Shanghai, China) for direct sequencing.

\section{Statistical analysis}

Statistical Package for the Social Sciences version 19.0 (IBM Corp., Armonk, NY, USA) was used for statistical analysis. Quantitative data are reported as means \pm standard deviations. Differences between AF patients and control subjects were analyzed by the Student $t$-test, and the chi-square test was employed for count data. Hardy-Weinberg equilibrium (HWE) was examined using the chi-square test. Multiple-logistic regression analysis was performed to analyze risk factors among the different groups. P values $<0.05$ were considered statistically significant.

\section{RESULTS}

\section{Characteristics of the study participants}

Differences in basic clinical characteristics between Uyghur and Han individuals are shown in Table 2. No statistically significant differences in age or gender were found between the case and control groups $(\mathrm{P}>0.05)$. Among Uyghur subjects, AF patients exhibited increased left atrial dimension (LAD) and TC and LDL-C levels $(\mathrm{P}<0.05)$ compared to the controls, whereas other factors did not significantly differ between the two groups $(\mathrm{P}>0.05)$. Within the Han study group, of the variables examined, there were significant differences in hypertension rate, LAD, TC and LDL-C levels $(\mathrm{P}<0.05)$ between AF patients and controls. 
Table 2. Comparison of the basic clinical features of Uyghur and Han individuals.

\begin{tabular}{l|c|c|c|c|c|c}
\hline & \multicolumn{3}{|c|}{ Uyghur } & \multicolumn{3}{c}{ Han } \\
\cline { 2 - 7 } & Control $(\mathrm{N}=140)$ & $\mathrm{AF}(\mathrm{N}=135)$ & P value & Control $(\mathrm{N}=147)$ & $\mathrm{AF}(\mathrm{N}=158)$ & $\mathrm{P}$ value \\
\hline Age $($ years $)$ & $51.51 \pm 11.718$ & $53.26 \pm 12.539$ & 0.232 & $53.25 \pm 12.019$ & $54.11 \pm 12.096$ & 0.536 \\
\hline Male/female & $67 / 73$ & $72 / 63$ & 0.399 & $82 / 65$ & $87 / 71$ & 0.909 \\
\hline Hypertension & $32(22.9 \%)$ & $41(30.4 \%)$ & 0.174 & $28(19.0 \%)$ & $48(30.4 \%)$ & $0.025^{*}$ \\
\hline Drinkers & $55(39.3 \%)$ & $57(42.2 \%)$ & 0.626 & $55(37.4 \%)$ & $64(40.5 \%)$ & 0.639 \\
\hline Smokers & $55(39.3 \%)$ & $51(37.8 \%)$ & 0.806 & $68(46.3 \%)$ & $74(47.1 \%)$ & 0.909 \\
\hline HR $(\mathrm{bpm})$ & $76.04 \pm 10.407$ & $76.76 \pm 11.439$ & 0.645 & $72.43 \pm 13.529$ & $75.16 \pm 13.344$ & 1.360 \\
\hline SBP $(\mathrm{mmHg})$ & $118.00 \pm 9.795$ & $119.85 \pm 12.327$ & 0.244 & $121.93 \pm 12.689$ & $118.97 \pm 14.193$ & 0.124 \\
\hline DBP $(\mathrm{mmHg})$ & $74.35 \pm 6.820$ & $75.68 \pm 8.951$ & 0.244 & $74.26 \pm 10.472$ & $74.49 \pm 10.903$ & 0.879 \\
\hline LAD $(\mathrm{mm})$ & $32.384 \pm 2.387$ & $35.941 \pm 4.846$ & $0.000^{*}$ & $34.358 \pm 2.863$ & $36.099 \pm 4.024$ & $0.001^{*}$ \\
\hline Uric acid $(\mu \mathrm{M})$ & $351.876 \pm 56.90$ & $366.726 \pm 96.45$ & 0.189 & $408.907 \pm 65.38$ & $388.334 \pm 85.76$ & 0.059 \\
\hline FBG $(\mathrm{mM})$ & $5.290 \pm 0.836$ & $5.497 \pm 1.265$ & 0.176 & $5.468 \pm 1.460$ & $5.862 \pm 1.467$ & 0.059 \\
\hline TG $(\mathrm{mM})$ & $1.436 \pm 0.636$ & $1.577 \pm 0.759$ & 0.160 & $1.717 \pm 0.669$ & $1.613 \pm 0.576$ & 0.242 \\
\hline TC $(\mathrm{mM})$ & $3.469 \pm 1.114$ & $3.946 \pm 1.123$ & $0.003^{*}$ & $4.086 \pm 0.907$ & $4.897 \pm 1.348$ & $0.000^{*}$ \\
\hline HLD-C $(\mathrm{mM})$ & $1.309 \pm 0.326$ & $1.244 \pm 0.473$ & 0.264 & $1.317 \pm 0.267$ & $1.257 \pm 0.277$ & 0.121 \\
\hline LDL-C $(\mathrm{mM})$ & $2.472 \pm 0.793$ & $2.878 \pm 0.516$ & $0.000^{*}$ & $2.652 \pm 0.919$ & $3.006 \pm 1.189$ & $0.020^{*}$ \\
\hline Albumin $(\mathrm{g} / \mathrm{L})$ & $46.26 \pm 6.264$ & $45.50 \pm 6.635$ & 0.406 & $45.29 \pm 5.657$ & $44.12 \pm 6.988$ & 0.198 \\
\hline BMI $\left(\mathrm{kg} / \mathrm{m}^{2}\right)$ & $27.00 \pm 4.28$ & $25.95 \pm 3.48$ & 0.183 & $25.01 \pm 3.26$ & $24.68 \pm 3.85$ & 0.622 \\
\hline
\end{tabular}

$\mathrm{AF}=$ atrial fibrillation; $\mathrm{HR}=$ heart rate; $\mathrm{SBP}=$ systolic blood pressure; $\mathrm{DBP}=$ diastolic blood pressure; $\mathrm{LAD}=$ left atrial diameter; $\mathrm{FBG}$ = fasting blood glucose; $\mathrm{TG}=$ triglycerides; $\mathrm{TC}=$ total cholesterol; HLD-C = high-density lipoprotein cholesterol; LDL-C = low-density lipoprotein cholesterol; BMI = body mass index. *Significantly different compared to the control group.

\section{PCR amplification}

A gel image of the PCR products obtained is shown in Figure 1. The DNA bands were clear and no non-specific bands were observed, suggesting that the amplification conditions were optimal and in line with the requirements of the experiment.

A

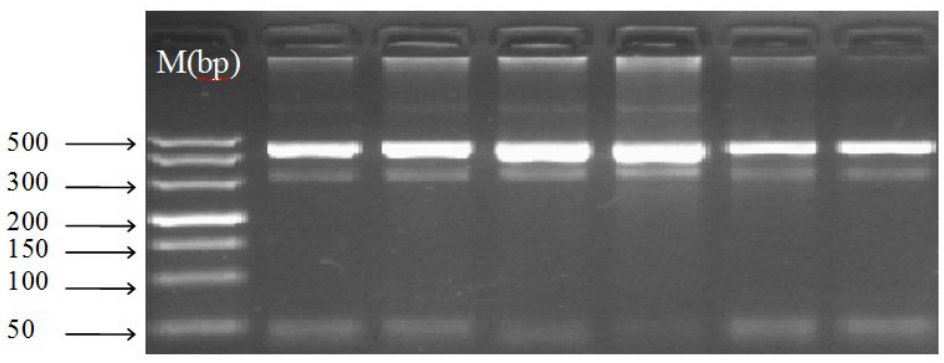

B

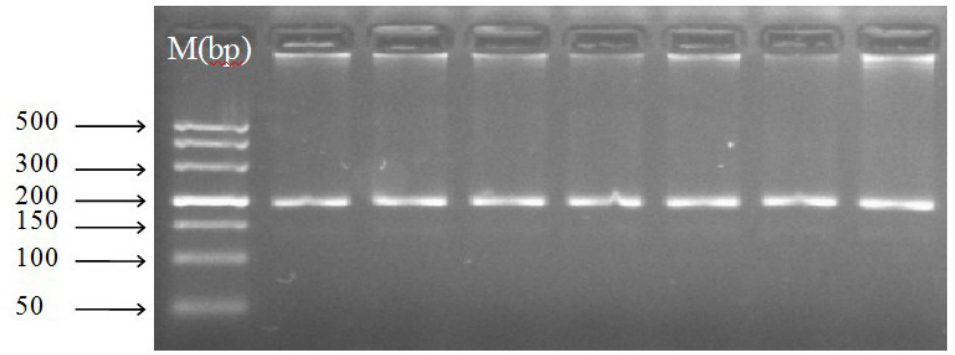

Figure 1. Electrophoresis of connexin 40 (A) $-44 \mathrm{G} / \mathrm{A}$ and $(\mathbf{B})+71 \mathrm{~A} / \mathrm{G}$ polymerase chain reaction products. 


\section{HWE test}

As shown in Table 3, the genotype distributions of both SNPs were consistent with HWE in the AF and control groups, suggesting that the study sample in the present article was representative of the general population.

Table 3. Hardy-Weinberg equilibrium test of connexin $40-44 \mathrm{G} / \mathrm{A}$ genotype frequencies in control and atrial fibrillation (AF) groups.

\begin{tabular}{|c|c|c|c|c|c|c|c|c|}
\hline \multirow[t]{2}{*}{ Genotype } & \multicolumn{4}{|c|}{ Controls } & \multicolumn{4}{|c|}{ AF patients } \\
\hline & $\begin{array}{c}\text { Observed } \\
\text { number }\end{array}$ & $\begin{array}{c}\text { Expected } \\
\text { number }\end{array}$ & Chi-square & P value & $\begin{array}{c}\text { Observed } \\
\text { number }\end{array}$ & $\begin{array}{c}\text { Expected } \\
\text { number }\end{array}$ & Chi-square & $P$ value \\
\hline Uyghur & & & \multirow[t]{4}{*}{58} & \multirow[t]{4}{*}{53.29} & & & \multirow[t]{4}{*}{1.21} & \multirow[t]{4}{*}{0.27} \\
\hline GG & 62 & 57.25 & & & 34 & 30.82 & & \\
\hline GA & 55 & 64.55 & & & 61 & 67.37 & & \\
\hline AA & 23 & 18.20 & & & 40 & 36.81 & & \\
\hline Han & & & \multirow[t]{4}{*}{2.64} & \multirow[t]{4}{*}{0.11} & & & \multirow[t]{4}{*}{1.37} & \multirow[t]{4}{*}{0.24} \\
\hline GG & 58 & 53.29 & & & 36 & 32.35 & & \\
\hline GA & 61 & 70.42 & & & 71 & 78.29 & & \\
\hline AA & 28 & 23.29 & & & 51 & 47.36 & & \\
\hline
\end{tabular}

\section{Cx40 -44G/A and $+71 A / G$ genotype and allele frequencies}

The -44G/A polymorphism has three possible genotypes (GG, GA, and AA; Figure 2), as does the $+71 \mathrm{~A} / \mathrm{G}$ variant (AA, AG, and GG; Figure 3). Pairwise linkage disequilibrium analysis revealed that in Uyghur and Han AF and control groups, these $\mathrm{Cx} 40$ polymorphisms were in perfect linkage $\left(\mathrm{D}^{\prime}=1, r^{2}=1\right)$. All subjects with allele $\mathrm{G}$ at position -44 carried allele $\mathrm{A}$ at +71 , and those with allele $A$ at position -44 carried allele $G$ at +71 , resulting in the genotype combinations $-44 \mathrm{AA} /+71 \mathrm{GG},-44 \mathrm{GG} /+71 \mathrm{AA}$, and $-44 \mathrm{GA} /+71 \mathrm{GA}$. Due to the perfect linkage disequilibrium between these two variants, only the -44G/A SNP was examined further in this study.

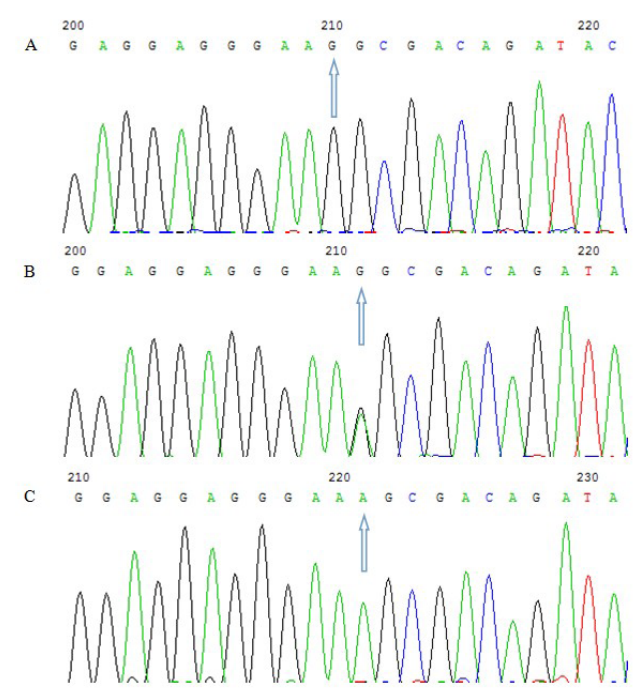

Figure 2. Connexin 40 -44G/A polymorphism sequencing results. A. Wild-type GG genotype; B. heterozygous GA genotype; C. homozygous AA genotype. The arrow indicates the affected residue. 


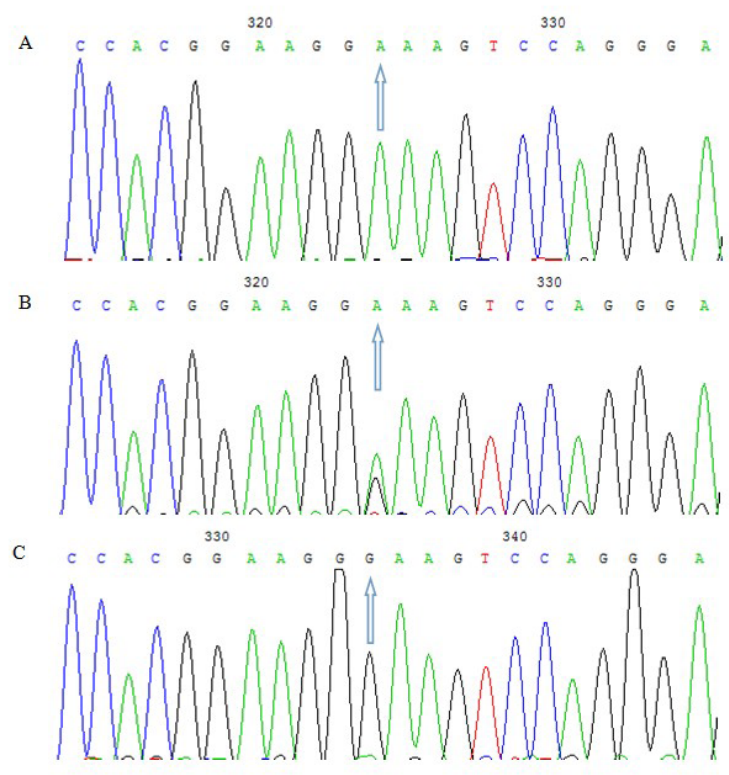

Figure 3. Connexin $40+71 \mathrm{~A} / \mathrm{G}$ polymorphism sequencing results. A. Wild-type AA genotype; B. heterozygous GA genotype; C. homozygous GG genotype. The arrow indicates the affected residue.

Within the Uyghur group, the distribution of genotypes and alleles significantly differed between controls and AF patients. GG, GA, and AA genotype frequencies were 25.2, 45.2, and $29.6 \%$, respectively, among AF patients and $44.3,39.3$, and $16.4 \%$, respectively, in the control group. The $\mathrm{G}$ and $\mathrm{A}$ alleles were carried by 47.8 and $52.2 \%$, respectively, of AF patients and 63.9 and $36.1 \%$, respectively, of control subjects $(\mathrm{P}<0.05)$. Among Uyghur individuals, the -44AA genotype and A allele were significantly more common in the AF group than the control group. Genotype analysis using several genetic models showed that A allele carriers (GA+AA) had a 2.357-fold increased risk of AF compared to subjects with the wild-type GG genotype [P $=0.007$, odds ratio $(\mathrm{OR})=2.357,95 \%$ confidence interval $(\mathrm{CI})=1.293-4.298$; Table 4]. The frequency of the $\mathrm{Cx} 40-44 \mathrm{~A} /+71 \mathrm{G}$ haplotype was significantly higher among $\mathrm{AF}$ patients than control subjects $(\mathrm{P}=0.005, \mathrm{OR}=1.621,95 \% \mathrm{CI}=1.153-2.281)$.

\section{Table 4. Distribution of connexin $40-44 \mathrm{G} / \mathrm{A}$ genotypes and alleles.}

\begin{tabular}{|c|c|c|c|c|c|c|c|c|c|c|}
\hline & \multicolumn{5}{|c|}{ Uyghur } & \multicolumn{5}{|c|}{ Han } \\
\hline & Control [N (\%)] & $\mathrm{AF}[\mathrm{N}(\%)]$ & Chi-square & OR $(95 \% \mathrm{CI})$ & $\mathrm{P}$ & Control [N (\%)] & $\mathrm{AF}[\mathrm{N}(\%)]$ & Chi-square & OR $(95 \% \mathrm{CI})$ & $\mathrm{P}$ \\
\hline \multicolumn{11}{|l|}{ Genotype } \\
\hline GG & $62(44.3)$ & $34(25.2)$ & \multirow[t]{3}{*}{7.09} & & \multirow[t]{3}{*}{$0.029 *$} & $58(39.5)$ & $36(22.8)$ & \multirow[t]{3}{*}{12.22} & & \multirow[t]{3}{*}{$0.002^{*}$} \\
\hline GA & $55(39.3)$ & $61(45.2)$ & & & & $61(41.5)$ & $71(44.9)$ & & & \\
\hline AA & $23(16.4)$ & $40(29.6)$ & & & & $28(19.0)$ & $51(32.3)$ & & & \\
\hline \multicolumn{11}{|c|}{ Dominant model } \\
\hline GG & $62(44.3)$ & $34(25.2)$ & \multirow[t]{2}{*}{7.99} & \multirow[t]{2}{*}{$2.357(1.293-4.298)$} & \multirow[t]{2}{*}{$0.007 *$} & $58(39.5)$ & $36(22.8)$ & \multirow[t]{2}{*}{6.69} & \multirow[t]{2}{*}{$2.232(1.208-4.124)$} & \multirow[t]{2}{*}{$0.015^{*}$} \\
\hline $\mathrm{GA}+\mathrm{AA}$ & $78(55.7)$ & $101(74.8)$ & & & & $89(60.5)$ & $122(77.2)$ & & & \\
\hline \multicolumn{11}{|c|}{ Recessive model } \\
\hline AA & $23(16.4)$ & $40(29.6)$ & \multirow[t]{2}{*}{5.53} & \multirow[t]{2}{*}{$0.444(0.224-0.881)$} & \multirow[t]{2}{*}{$0.028^{*}$} & $28(19.0)$ & $51(32.3)$ & \multirow[t]{2}{*}{4.45} & \multirow[t]{2}{*}{$0.498(0.259-0.957)$} & \multirow[t]{2}{*}{$0.051^{*}$} \\
\hline $\mathrm{GG}+\mathrm{GA}$ & $117(83.6)$ & $95(70.4)$ & & & & $119(81.0)$ & $107(67.7)$ & & & \\
\hline \multicolumn{2}{|c|}{ Co-additive model } & & & & & & & & & \\
\hline GA & $55(39.3)$ & $61(45.2)$ & \multirow[t]{2}{*}{0.74} & \multirow[t]{2}{*}{$0.781(0.445-1.372)$} & \multirow[t]{2}{*}{0.474} & $61(41.5)$ & $71(44.9)$ & \multirow[t]{2}{*}{0.18} & \multirow[t]{2}{*}{$0.885(0.506-1.548)$} & \multirow[t]{2}{*}{0.776} \\
\hline GG+AA & $85(60.7)$ & $74(54.8)$ & & & & $86(58.5)$ & $87(55.1)$ & & & \\
\hline \multicolumn{2}{|c|}{ Allele frequency } & & & & & & & & & \\
\hline G & $179(63.9)$ & $129(47.8)$ & \multirow[t]{2}{*}{7.74} & \multirow[t]{2}{*}{$1.621(1.153-2.281)$} & \multirow[t]{2}{*}{$0.005^{*}$} & $177(60.2)$ & $143(45.3)$ & \multirow[t]{2}{*}{13.65} & \multirow[t]{2}{*}{$1.83(1.326-2.525)$} & \multirow[t]{2}{*}{$0.0002^{*}$} \\
\hline A & $101(36.1)$ & $141(52.2)$ & & & & $117(39.8)$ & $173(54.7)$ & & & \\
\hline
\end{tabular}

$\mathrm{AF}=$ atrial fibrillation; $\mathrm{OR}=$ odds ratio; $\mathrm{CI}=$ confidence interval. * Significantly different compared to the control group.

Genetics and Molecular Research 15 (4): gmr15048628 
In the Han study population, the distribution of genotypes and alleles was also significantly different between controls and AF patients. The frequencies of GG, GA, and AA genotypes were $22.8,44.9$, and $32.3 \%$, respectively, in the AF group and 39.5, 41.5, and $19.0 \%$, respectively, among controls. G and A allele frequencies were 45.3 and $54.7 \%$, respectively, among AF patients and 60.2 and $39.8 \%$, respectively, in the control group ( $\mathrm{P}$ $<0.05)$. The prevalence of the -44AA genotype was significantly higher in the AF group than the control group, as was that of the A allele. Using genotype analysis under several genetic models, A allele carriers (GA+AA) were found to be at a 2.232-fold increased risk of $\mathrm{AF}$ compared with individuals carrying the wild-type $\mathrm{GG}$ sequence $(\mathrm{P}=0.015, \mathrm{OR}=$ $2.232,95 \% \mathrm{CI}=1.208-4.124$; Table 4). Haplotype analysis revealed the frequency of $\mathrm{Cx} 40$ $-44 \mathrm{~A} /+71 \mathrm{G}$ to be significantly higher in the $\mathrm{AF}$ group than in the control group $(\mathrm{P}=0.0002$, $\mathrm{OR}=1.83,95 \% \mathrm{CI}=1.326-2.525)$.

No significant difference was detected between the Uyghur and Han AF groups in the distribution of genotypes (chi-square $=0.34, \mathrm{P}=0.84$ ) or alleles (chi-square $=0.37, \mathrm{P}=0.54$ ).

After using an unconditional logistic regression model to adjust for AF risk factors (age, gender, tobacco and alcohol consumption, blood pressure, fasting blood glucose, TG, TC, HDL-C, and LDL-C), our results suggested that Cx40 genetic polymorphisms increase AF risk in both Uyghur and Han populations (Table 5).

\begin{tabular}{l} 
Table 5. Logistic regression analysis. \\
\begin{tabular}{l|c|c|c|c|c|c|c|c|c|c|c}
\hline \\
\hline
\end{tabular} \\
\hline
\end{tabular}

$\mathrm{SE}=$ standard error; $\mathrm{OR}=$ odds ratio $; \mathrm{CI}=$ confidence interval; $\mathrm{LAD}=$ left atrial dimension; $\mathrm{TC}=$ total cholesterol; LDL-C $=$ low-density lipoprotein cholesterol. *Significantly different compared to the control group.

\section{DISCUSSION}

In this study, we found that $\mathrm{Cx} 40$ gene polymorphisms were correlated with $\mathrm{AF}$ among both Uyghur and Han subjects. This is the first investigation to test the association between AF and Cx40 SNPs in the Chinese population.

In the heart, fast and coordinated propagation of cardiac action potentials is mediated by intercellular gap junction channels constructed from membrane-spanning protein subunits called connexins, which are crucial for the conduction of electrical impulses. Connexins are primarily located in the intercalated discs at end-to-end intercellular connections (Severs, 1990). The presence of an arrhythmogenic substrate and initiating triggers is known to determine vulnerability to heart arrhythmias. Initiating triggers of AF most often originate from firing foci in the pulmonary veins and/or superior cava vein (Chaldoupi et al., 2009). Long-term AF gives rise to electrical and structural remodeling that favor the reoccurrence or perpetuation of the condition. Electrical remodeling associated with $\mathrm{AF}$ also induces changes in the effective refractory period. Modifications to gap junctions and connexins have also been reported as part of such alterations in AF pathology.

Genetics and Molecular Research 15 (4): gmr15048628 
Previous studies have suggested that the $\mathrm{Cx} 40$ gene $-44 \mathrm{G} / \mathrm{A}$ and $+71 \mathrm{~A} / \mathrm{G}$ polymorphisms are associated with AF in people of European ancestry (Firouzi et al., 2004). The present study showed that these two variants are in perfect linkage disequilibrium, consistent with previous research. Such non-random association at this locus is likely due to the short distance between these two alleles.

In our study, we found that compared with the wild-type GG genotype, GA+AA genotypes showed 2.357- and 2.232-fold increased risk of AF among Uyghur and Han participants, respectively. These findings suggest a strong association between $\mathrm{Cx} 40$ polymorphisms and susceptibility to AF in the Uyghur and Han populations of Xinjiang.

Previously published data suggest that Cx40 is mainly expressed in the atria and the cardiac conduction system. Increased atrial vulnerability and propensity to arrhythmias have been reported in Cx40-deficient mice (Hagendorff et al., 1999; Verheule et al., 1999). Using the conscious goat model, van der Velden et al. (2000) found that Cx40 gap junction remodeling may be related to the pathogenesis of sustained $\mathrm{AF}$, and observed decreased $\mathrm{Cx} 40$ distribution and quantity during this condition in the goat atrial appendage. However, contrary to these results, some researchers have reported a 2.7-fold increase in $\mathrm{Cx} 40$ expression in the atria of human AF sufferers (Polontchouk et al., 2001). Moreover, in another human open-heart surgery study, it was also suggested that conduction velocity during sinus rhythm and atrial pacing is reduced owing to an increase in the proportion of Cx40 (Dupont et al., 2001). Therefore, Cx40 genetic variations may play an important role in promoting AF (Dbouk et al., 2009).

Groenewegen et al. (2003) originally found that two closely linked polymorphisms in the promoter region of the gene encoding $\mathrm{Cx} 40,-44 \mathrm{G} / \mathrm{A}$ and $+71 \mathrm{~A} / \mathrm{G}$, were strongly associated with familial atrial standstill, and the occurrence of these SNPs in the general population was estimated to be approximately 7\%. Firouzi et al. (2004) were the first to connect susceptibility to AF to these $\mathrm{Cx} 40$ promoter variations. The study of Hauer et al. (2006) indicated that these polymorphisms are associated with the atrial electrophysiological substrate favoring reentrant mechanisms for initiation of AF. Meanwhile, researchers from Taiwan, China (Juang et al., 2007), demonstrated a significant association between these two SNPs and AF, and suggested that the $\mathrm{Cx} 40-44 \mathrm{~A} /+71 \mathrm{G}$ haplotype is associated with elevated risk of this condition. The present study was undertaken on the basis of our previous epidemiological investigation. After multivariate adjustment, a significant difference between $\mathrm{Cx} 40$ polymorphism genotypes in terms of $\mathrm{AF}$ risk remained evident. This demonstrates that such SNPs may be involved in the occurrence and development of AF, and may increase susceptibility to this condition among both Uyghur and Han populations in the Xinjiang region of China.

However, Wirka et al. (2011) reported that the $-44 \mathrm{G} /$ A promoter SNP does not influence $\mathrm{Cx} 40$ expression or AF risk. In contrast to our results, they demonstrated a lack of association between this variant and AF with an effect size of 1.18 or greater in a population of European ancestry. Such inconsistency could be partially ascribed to ethnicity-specific genetic effects or differences in baseline patient characteristics. In summary, in Uyghur and Han populations of Xinjiang, frequencies of the -44AA genotype and A allele were significantly higher among AF patients, suggesting that $\mathrm{Cx} 40$ gene polymorphisms are associated with this pathology, and that the A allele may be an AF susceptibility factor. However, whether this allele influences $\mathrm{Cx} 40$ levels in vivo and the manner in which it affects the function of this protein in AF remain unknown. Further studies are therefore required.

Genetics and Molecular Research 15 (4): gmr15048628 


\title{
Conflicts of interest
}

The authors declare no conflict of interest.

\section{ACKNOWLEDGMENTS}

\author{
The First Affiliated Hospital of Xinjiang Medical University provided the experimental \\ platform. Research supported by the Natural Science Foundation of China (NSFC; \#81260036).
}

\section{REFERENCES}

Chaldoupi SM, Loh P, Hauer RN, de Bakker JM, et al. (2009). The role of connexin40 in atrial fibrillation. Cardiovasc. Res. 84: 15-23. http://dx.doi.org/10.1093/cvr/cvp203

Dbouk HA, Mroue RM, El-Sabban ME and Talhouk RS (2009). Connexins: a myriad of functions extending beyond assembly of gap junction channels. Cell Commun. Signal. 7: 4. http://dx.doi.org/10.1186/1478-811X-7-4

Dupont E, Ko Y, Rothery S, Coppen SR, et al. (2001). The gap-junctional protein connexin40 is elevated in patients susceptible to postoperative atrial fibrillation. Circulation 103: 842-849. http://dx.doi.org/10.1161/01.CIR.103.6.842

European Society of Hypertension-European Society of Cardiology Guidelines Committee (2003). 2003 European Society of Hypertension-European Society of Cardiology guidelines for the management of arterial hypertension. $J$. Hypertens. 21: 1011-1053. http://dx.doi.org/10.1097/00004872-200306000-00001

Firouzi M, Ramanna H, Kok B, Jongsma HJ, et al. (2004). Association of human connexin40 gene polymorphisms with atrial vulnerability as a risk factor for idiopathic atrial fibrillation. Circ. Res. 95: e29-e33. http://dx.doi.org/10.1161/01. RES.0000141134.64811.0a

Fuster V, Rydén LE, Cannom DS, Crijns HJ, et al.; Task Force on Practice Guidelines, American College of Cardiology/ American Heart Association; Committee for Practice Guidelines, European Society of Cardiology; European Heart Rhythm Association; Heart Rhythm Society (2006). ACC/AHA/ESC 2006 guidelines for the management of patients with atrial fibrillation-executive summary: a report of the American College of Cardiology/American Heart Association Task Force on Practice Guidelines and the European Society of Cardiology Committee for Practice Guidelines (Writing Committee to Revise the 2001 Guidelines for the Management of Patients with Atrial Fibrillation). Eur. Heart J. 27: 1979-2030.

Groenewegen WA, Firouzi M, Bezzina CR, Vliex S, et al. (2003). A cardiac sodium channel mutation cosegregates with a rare connexin40 genotype in familial atrial standstill. Circ. Res. 92: 14-22. http://dx.doi.org/10.1161/01. RES.0000050585.07097.D7

Hagendorff A, Schumacher B, Kirchhoff S, Lüderitz B, et al. (1999). Conduction disturbances and increased atrial vulnerability in Connexin40-deficient mice analyzed by transesophageal stimulation. Circulation 99: 1508-1515. http://dx.doi.org/10.1161/01.CIR.99.11.1508

Hauer RN, Groenewegen WA, Firouzi M, Ramanna H, et al. (2006). Cx40 polymorphism in human atrial fibrillation. $A d v$. Cardiol. 42: 284-291. http://dx.doi.org/10.1159/000092579

Hu D and Sun Y (2008). Epidemiology, risk factors for stroke, and management of atrial fibrillation in China. J. Am. Coll. Cardiol. 52: 865-868. http://dx.doi.org/10.1016/j.jacc.2008.05.042

January CT, Wann LS, Alpert JS, Calkins H, et al.; ACC/AHA Task Force Members (2014). 2014 AHA/ACC/HRS guideline for the management of patients with atrial fibrillation: executive summary: a report of the American College of Cardiology/American Heart Association Task Force on practice guidelines and the Heart Rhythm Society. Circulation 130: 2071-2104. http://dx.doi.org/10.1161/CIR.0000000000000040

Juang JM, Chern YR, Tsai CT, Chiang FT, et al. (2007). The association of human connexin 40 genetic polymorphisms with atrial fibrillation. Int. J. Cardiol. 116: 107-112. http://dx.doi.org/10.1016/j.ijcard.2006.03.037

Mu HYT, Ma YT, Lu WH, Zhang YM, et al. (2007a). An analysis on racial and clinical characters for 1436 patients with atrial fibrillation in hospitalization. Chin. J. Card. Pacing Electrophysiol. 21: 125-127.

Mu HYT, Lu WH, Ma YT, Zhang YM, et al. (2007b). Clinical analysis for nonvalvular atrial fibrillation with thromboembolism patients. Chin. J. Card. 35: 671.

Mu HYT, Lu WH, Ma YT, Zhang YM, et al. (2008). The comparison of clinical features in atrial fibrillation between the Uyghurs and Hans patients. Chin. J. Card. Pacing Electrophysiol. 22: 216-218.

Polontchouk L, Haefliger JA, Ebelt B, Schaefer T, et al. (2001). Effects of chronic atrial fibrillation on gap junction

Genetics and Molecular Research 15 (4): gmr15048628 
distribution in human and rat atria. J. Am. Coll. Cardiol. 38: 883-891. http://dx.doi.org/10.1016/S07351097(01)01443-7

Severs NJ (1990). The cardiac gap junction and intercalated disc. Int. J. Cardiol. 26: 137-173. http://dx.doi. org/10.1016/0167-5273(90)90030-9

Sun Y, Hills MD, Ye WG, Tong X, et al. (2014). Atrial fibrillation-linked germline GJA5/connexin40 mutants showed an increased hemichannel function. PLoS One 9: e95125. http://dx.doi.org/10.1371/journal.pone.0095125

van der Velden HM, Ausma J, Rook MB, Hellemons AJ, et al. (2000). Gap junctional remodeling in relation to stabilization of atrial fibrillation in the goat. Cardiovasc. Res. 46: 476-486. http://dx.doi.org/10.1016/S0008-6363(00)00026-2

Verheule S, van Batenburg CA, Coenjaerts FE, Kirchhoff S, et al. (1999). Cardiac conduction abnormalities in mice lacking the gap junction protein connexin40. J. Cardiovasc. Electrophysiol. 10: 1380-1389. http://dx.doi. org/10.1111/j.1540-8167.1999.tb00194.x

Wirka RC, Gore S, Van Wagoner DR, Arking DE, et al. (2011). A common connexin-40 gene promoter variant affects connexin-40 expression in human atria and is associated with atrial fibrillation. Circ Arrhythm Electrophysiol 4: 8793. http://dx.doi.org/10.1161/CIRCEP.110.959726

Yao J, Ma YT, Huang Z, Liu F, et al. (2010). Prevalence and relative risk factors of atrial fibrillation in Xinjiang adult population. Chin. J. Card. Arrhythm. 5: 392-396.

Genetics and Molecular Research 15 (4): gmr15048628 